\title{
$\mathrm{X}_{0}$ IJRSLCE \\ International Journal \\ for Research on \\ Service-Learning \& \\ Community Engagement
}

Article 1

2017

\section{Welcome to the Volume}

\section{Lane Perry}

Dan Richard

This article was originally published at:

https://journals.sfu.ca/iarslce/index.php/journal/article/view/306/196

Recommended Citation

Perry, L. \& Richard, D. (2017). Welcome to the volume. International Journal of Research on Service-Learning and Community Engagement, 5(1), 1-3. 


\section{Welcome to the Volume Lane Perry \& Dan Richard Co-Editors}

\section{Introduction}

Welcome to the fifth volume of the International Journal of Research on Service-Learning and Community Engagement (IJRSLCE), the annual, online, peer-reviewed publication of the International Association for Research on Service-Learning and Community Engagement (IARSLCE). IARSLCE is the premier network for scholars studying teaching, learning, and research in community engagement and civic and public life. The purpose of the journal is to make available to educational practitioners, researchers, and policymakers current, high-quality research and theory on service-learning and campuscommunity engagement.

The 2017 volume of IJRSLCE comprises an array of submissions offering insight into previously under-examined issues, outcomes, impacts, and/or approaches that help to inform current and future research and practice within and across the field. The articles in each section are summarized here.

\section{Advances in Theory and Methodology}

This section of the journal focuses on new conceptualizations of service-learning and community engagement, propose new theories and methodologies for researchers and practitioners, or address new applications of theories and/or concepts. In the current issue, one theoretical article appears in the Advances section. In "From Community Engagement to Community Emergence: The Holistic Program Design Approach," Brad Olson and Mark Brennan provide a framework for developing, implementing, and assessing university community-engagement efforts. This framework focuses on social interaction related to local and mutual aims as the venue for beneficial community development.

\section{Community Partnerships and Impacts}

This section addresses impacts of service-learning and community engagement activities on a community or a part of a community (e.g., a service agency or governmental institution), particularly impacts that are informed by participatory methodologies and through sustained engagement with community partners. This section also addresses theories, frameworks, and methodologies that allow such partnerships to flourish. In this issue, Alan Bloomgarden, in his conceptual article "Out of the Armchair: About Community Impact," challenges authors in the field with a wish list of journal titles.

\section{Faculty Roles and Institutional Issues}

This section centers on theory or conceptual frameworks that inform faculty roles and responsibilities in service-learning and community engagement, as well as the institutional contexts that influence faculty work. In the current issue, two research articles comprise this section. Spoma Jovanovic, Kristin Moretto, and Kathleen Edwards address faculty identity in "Moving from Thin to Thick Conceptions of Civic Engagement: Faculty Identity and Goals for Democratic Learning"; and Tiesha Martin, Carrie Lecrom, and Jill Lassiter examine faculty emotional responses in "Hearts on Our Sleeves: Emotions Experienced by Service-Learning Faculty."

\section{International Service-Learning and Community Engagement Research}

This journal section focuses on supporting the advancement of the community engagement movement by primarily showcasing studies that are facilitated in non-U.S. settings or have direct implications for research in international contexts. In this issue, international service-learning and community engagement are addressed across three research studies and two conceptual articles. The research articles include: 
"Service and Service-Learning in International Baccalaureate High Schools: An International Comparison of Outcomes and Moderators," by Shelley Billig; "The Institutionalization of Service-Learning at Spanish Universities," by Raquel Heras-Colas, Mariona Masgrau-Juanola, and Pere Soler-Maso; and "Does Location Really Matter? Exploring the Role of Place and Nation in Service-Learning Experiences," by Elizabeth Niehaus and Crystal Garcia. The conceptual articles include: "Indigenous Perspectives in Community Service-Learning in Higher Education: An Examination of the Kenyan Context," by Charlene VanLeeuwen, Lori Weeks, and Linyuan Guo-Brennan; and "Updates to the 'Common Rule': Implications for International Service-Learning and Community Engagement Research," by Johanna Phelps-Hillen.

\section{Student Outcomes (Primary, Secondary, and Higher Education)}

As our knowledge of service-learning's impact on student learning continually evolves and the questions become more informed, there is a continual need to understand the deeply complex aspects associated with this engaging pedagogy. In this issue, these complexities are addressed in two research studies: "The Effects of Participation in Alternative Break: An Alumni Sample Study," by Zac Johnson and Matthew Martin; and "Pre-Service Educator Preparation to Teach Children with Disabilities through ServiceLearning," by James Zagrodnik, Natalie Williams, and Patrick Leytham.

\section{Book Reviews}

The current issue includes two book reviews of recent 2017 publications. Monica Kowal recognizes the "evolution of the profession" in her review of The Community Engagement Professional in Higher Education: A Competency Model for an Emerging Field (edited by Lina Dostilio). In Christopher Adam Ray's review of Where's the Wisdom in Service-Learning (edited by Robert Shumer) generations are juxtaposed. Christopher steps inside the minds of some of the most sagacious scholars in the field of service-learning and community engagement, offering a renewed and refreshing perspective on this work.

\section{Conclusion and Thank You}

Like anything worth investing in, the production of this journal truly does take a village. In this, we are forever indebted to the section editors, peer review board members, and peer reviewers at-large, whose fingers and minds informed the source code associated with the 2017 volume. This village includes: Andy Furco and Elaine Ward (Advances in Theory and Methodology); Alan Bloomgarden and Burton Bargerstock (Community Partnerships and Impacts); Christine Cress and Lina Dostilio (Faculty Roles and Institutional Issues); Carol Ma and Glenn Bowen (International Service-Learning and Community Engagement); Tami Moore, Sue Root, and Billy O'Steen (Student Outcomes, K- 20); and the newly established Peer Review Board, whose members include Ethan Kolek, Bojana Culum, Jillian White, Kevin Hemer, Rachel Samuelson, Mitzi Ritzman, Diane Shingledecker, Sarah Stokamer, Susan Harris, and Tommy Van Cleave.

The section editors represent the editorial team's first line of quality control, and their preliminary review of the manuscripts, distribution to peer reviewers, synthesis of peer reviewer feedback, and work with authors to help them shape their articles for publication is the lifeblood of the journal. We would like to extend a special thank you to Sue Root and Kateryna Kent for their leadership in managing the flow of manuscripts and completing the layout of the journal, and we thank Brad Arndt for his expert copyediting, timely communication with authors, and commitment to IJRSLCE. Finally, we wish to express our gratitude to IARSLCE's Board of Directors for their support of the journal and the advancement of research in the field. 
3 | International Journal of Research on Service-Learning and Community Engagement

\section{Author Note:}

Lane Perry is Director of the Center for Service Learning at Western Carolina University.

Dan Richard is an Associate Professor and Director of the Office of Faculty Enhancement at the University of North Florida. 